The 2 nd Conf. of SSFOP "Future of Ornamental Plants in Egypt and Arab World", Cairo,

Egypt, 21/2/2016

Scientific J. Flowers \& Ornamental Plants

www.ssfop.com/journal

ISSN: 2356-7864

\title{
EFFECT OF NATURAL ACTIVATOR (BIOHORM) AND HUMIC ACID ON GROWTH AND QUALITY OF CYCAS PLANT
}

\author{
Boshra A. El-Sayed*, T.M. Noor El-Deen*, Lobna M. Abdel-Galeil ${ }^{* *}$ and Warda A. Aly ${ }^{*}$ \\ * Ornamental Plants and Landscape Gardening Res. Dept., Hort. Res. Inst., ARC, Giza, Egypt. \\ ** Central Lab. for Res. \& Date Palm Develop., Hort. Res. Inst., ARC, Giza, Egypt.
}



Scientific J. Flowers \& Ornamental Plants, 3(1):79-86 (2016).

Received:

10/1/2016

Revised by:

Prof. Dr. E.S. Nofal, Kafr El-Sheikh Univ.

Prof. Dr. A.Z. Sarhan, Cairo Univ.

ABSTRACT: This investigation was conducted under open field conditions at the Experimental Farm of Hort. Res. Inst., ARC, Giza, Egypt during 2014 and 2015 seasons to find out the response of twoyears-old cycas plant (Cycas revoluta, Thunb.) grown in $20-\mathrm{cm}$ diameter plastic pots filled with about $2.5 \mathrm{~kg}$ of a mixture of sand, clay and peatmoss $(1: 1: 1, \mathrm{v}: \mathrm{v}: \mathrm{v})$ to natural activator viz. BioHorm at 1 and $3 \mathrm{ml} / 1$ and commercial humic acid liquid fertilizer (high $\mathrm{K}$ humic acid) at the rate of $5 \mathrm{ml} / \mathrm{l}$ (as a foliar spray 6 times with one month interval) and their interactions.

The results showed that all vegetative and root growth parameters, were significantly improved over control in response to either single or combined treatments applied in this study, but the best individual treatments were humic acid at $5 \mathrm{ml} / 1$ followed by BioHorm at $3 \mathrm{ml} / 1$. The best improvement was obtained when combining BioHorm at $3 \mathrm{~m} / 1$ + humic acid at $5 \mathrm{ml} / \mathrm{l}$ which gave high means of vegetative and root growth parameters at all in the two seasons. A similar trend was also observed as well regarding the content of chlorophyll a, b, carotenoids, $\mathrm{N}, \mathrm{P}, \mathrm{K}$, total carbohydrates $\%$ and total indoles in the leaves, but the phenols content was decreased in all treatments.

Hence, it is recommended to spray the cycas plants with combination of BioHorm at $3 \mathrm{ml} / 1+5 \mathrm{ml} / 1$ humic acid to score the best growth performance and highest quality.

Key words: Cycas revoluta Thunb., natural activator, humic acid, vegetative growth, root growth.

\section{INTRODUCTION}

Cycas revoluta, Thunb. (Fam. Cycadaceae), Sage palm is a graceful palmlike tree or shrub, becoming 6-10 feet high, with the trunk simple or branching. Leaves long and recurved (2-7 feet), pinnae numerous, subopposite curved downward, narrow, stiff, acute, terminating in a spinelike tip, dark shining green. This is the most common cycas in conservatories, Javanese origin, it is usually found in all of the better parks and gardens, it is suitable as a center about which to arrange other ornamental shrubs, this species are of slow growth. (Bailey, 1950).

Several reports were suggested to restore the natural biological balance which is disturbed by the misuse of chemical fertilizers, besides improving growth and keeping quality of the plants. In this regard, El-Sayed (2012) on seashore paspalum reported that combining between humic acid at $20 \mathrm{ml} / 1$ and Oligo-X (an algae extract) at $1.5 \mathrm{ml} / \mathrm{l}$ level gave the tallest plants, best coverage, more number of plants/pot, heaviest fresh and dry weights as well as the 
highest content of pigments in the leaves and of total soluble sugars, indoles and phenols in the herb. In another study, El-Sayed et al. (2015) recommended to spray verdure of seashore paspalum turf with combination of SBG (3 ml/l) + Ascobien (9 g/l) + BioHorm $(1 \mathrm{ml} / \mathrm{l})$ during the growth stage to score the best growth performance and highest quality.

Humic acid and humates are being used widely now for enhancing growth and quality of most crops, as they provide soil microbs with energy, improve nutrients relation in the soil and increase the water holding capacity (Dorer and Peacock, 1997). Evans and Li (2003) revealed that humic acid at $2500 \mathrm{ppm}$ increased lateral root number and length as well as roots dry weight of Cathranthus roseus, Pelargonium hortorum, Tagetes patula and Viola tricolor. El-Sherbeny et al. (2012) declared that the highest growth parameters or biomass represented by leaves and roots of turnip plant were obtained with NPK or humic acid, but it can be recommended to use humic acid as an organic fertilizer to produce organic products. Also, humic acid increased carbohydrates, minerals, total lipids and fatty acids contents, El-Fouly et al. (2014) on cordylin plant, found that spray the foliage of one-year-old transplants of Cordaline terminalis, every month with citreen and humic acid at $5 \mathrm{ml} / 1$ gave the best performance and highest quality.

This work, however aims to study the role of natural activators and commercial humic acid liquid fertilizer (high $\mathrm{K}$ humic acid) and the interactions between them on improving growth and quality of cycas plants under our local climatic conditions.

\section{MATERIALS AND METHODS}

The current investigation was performed under the open field conditions at the Experimental Farm of Hort. Res. Inst., ARC, Giza, Egypt throughout the two consecutive seasons of 2014 and 2015 to study the effect of some natural activators on growth and chemical composition of cycas plants.
Therefore, 2-years-old plants of Cycas revoluta, Thunb. of about $35-40 \mathrm{~cm}$ height with 2-3 leaves were planted on March, $15^{\text {th }}$ for the two seasons in 20-cm-diameter plastic pots filled with about $2.5 \mathrm{~kg}$ sand + clay + peat at (1:1:1, v:v:v). The physical and chemical properties of the used sand + clay are shown in Table (1), while those of the used peatmoss are averaged in Table (2).

After 15 days from planting (on April, $1^{\text {st }}$ ), the transplants received the following fertilization treatments:

1- No fertilization (referred to as control).

2- A commercial humic acid liquid organic fertilizer (high $\mathrm{K}$ humic acid) was applied as foliar spray at the rate of $5 \mathrm{ml} / 1$ till the solution was run off.

3- BioHorme at the rate of $1 \mathrm{ml} / \mathrm{l}$ (natural enzymatic activator that contains cytokinin, riboflavin, niacin, thiamin as well as citric, L. ascorbic and volvic acids + L-free amino acids $(20 \%)+\operatorname{Mo}(4 \%)+\operatorname{Co}(0.005 \%)$.

4- BioHorme at the rate of $3 \mathrm{ml} / \mathrm{l}$.

5- The previous treatments were combined to give the following 2 combinations:

a. Humic acid at $5 \mathrm{ml} / \mathrm{l}+$ BioHorm at $1 \mathrm{ml} / 1$.

b. Humic acid at $5 \mathrm{ml} / \mathrm{l}+$ BioHorm at $3 \mathrm{ml} / 1$.

The pots were arranged in a completely randomized design (Mead et al., 1993), with 3 replicates for each treatment as each replicate contained 3 pots.

At the end of each season, data were recorded as follows: plant height $(\mathrm{cm})$, number of leaves and leavlets/plant, stem diameter at the base $(\mathrm{cm})$, number of roots, root length $(\mathrm{cm})$, as well as leaves, stem and roots fresh and dry weights $(\mathrm{g})$. In fresh leaf samples, photosynthetic pigments (chlorophyll a, b and carotenoids (mg/g f.w.) were determined according to the method described by Moran (1982). However, in dry 
Table 1. Physical and chemical analysis of the used sand and clay in the two seasons.

\begin{tabular}{|c|c|c|c|c|c|c|c|c|c|c|c|c|c|c|}
\hline \multirow{2}{*}{  } & \multicolumn{4}{|c|}{ Particle size distribution (\%) } & \multirow{2}{*}{ S.P. } & \multirow{2}{*}{$\begin{array}{c}\text { E.C. } \\
\text { (ds } / \mathbf{m})\end{array}$} & \multirow[b]{2}{*}{ pH } & \multicolumn{4}{|c|}{ Cations (meq/l) } & \multicolumn{3}{|c|}{ Anions (meq/l) } \\
\hline & $\begin{array}{l}\text { Coarse } \\
\text { sand }\end{array}$ & $\begin{array}{l}\text { Fine } \\
\text { sand }\end{array}$ & Silt & Clay & & & & $\mathrm{Ca}^{++}$ & $\mathbf{M g}^{++}$ & $\mathrm{Na}^{+}$ & $\mathbf{K}^{+}$ & $\mathrm{HCO}_{3}^{-}$ & $\mathrm{Cl}^{-}$ & $\mathrm{SO}_{4}^{--}$ \\
\hline Clayey & 7.46 & 16.75 & 34.53 & 40.89 & 41.76 & 2.18 & 8.33 & 16.93 & 9.33 & 20.44 & 0.37 & 3.82 & 1.46 & 41.79 \\
\hline Sandy & 18.72 & 71.28 & 4.76 & 5.34 & 21.83 & 1.58 & 8.20 & 2.65 & 2.48 & 21.87 & 0.78 & 3.85 & 13.00 & 10.93 \\
\hline
\end{tabular}

Table 2. Physical and chemical analysis of the used peatmoss in the two seasons.

\begin{tabular}{llll}
\hline Organic matter & $90-95 \%$ & $\mathbf{N}$ & $1.09 \%$ \\
Ash & $5-10 \%$ & $\mathbf{P}$ & $0.23 \%$ \\
Density (Vol. dry) & $80-90 \mathrm{mg} / 1$. & $\mathbf{K}$ & $1.77 \%$ \\
pH value & 3.4 & $\mathbf{F e}$ & $421 \mathrm{ppm}$ \\
Water relation capacity & $60-75 \%$ & $\mathbf{M n}$ & $27 \mathrm{ppm}$ \\
Salinity & $0.3 \mathrm{~g} / 1$ & $\mathbf{Z n}$ & $41 \mathrm{ppm}$ \\
\hline
\end{tabular}

samples, the content of total carbohydrates (Herbert et al., 1971), nitrogen using microKjeldahle method (Jackson, 1973), phosphorus colorimetrically as recommended by Cottenie et al. (1982) and potassium using flame-photometer (Jackson, 1973), all of them as percentage were measured. Total indoles and total phenols (mg/100 g f.w.) were measured according to the method of Saric et al. (1967), A.O.A.C. (1990) and William et al. (1965).

Data were then tabulated and subjected to analysis of variance using SAS Institute program (1994), following Duncan's Multiple Range Test (Duncan, 1955) to detect the significancy among means of the various treatments.

\section{RESULTS AND DISCUSSION}

\section{Effect of fertilization treatments on:}

\section{Vegetative growth parameters:}

Data presented in Tables (3 and 4) cleared that all vegetative growth parameters were improved with all treatments applied in this study, expressed as plant height $(\mathrm{cm})$, Number of leaves/plant, stem diameter, number of roots and root length $(\mathrm{cm})$, as well as fresh and dry weight of leaves, stem and roots $(\mathrm{g})$. However, the dominance in both seasons was for the interaction treatment between BioHorm $3 \mathrm{ml} / 1$ and humic acid at 5 $\mathrm{ml} / \mathrm{l}$, as such combination increased the means of all previous parameters to the highest values comparing with control and other individual treatments in the two seasons. Humic acid alone at $5 \mathrm{ml} / \mathrm{l}$ or combined with BioHorm at $3 \mathrm{ml} / 1$ improved all parameters. In this concern, humic acid at $5 \mathrm{ml} / \mathrm{l}+$ BioHorm at $3 \mathrm{ml}$ gave the highest values of fresh and dry weights of leaves, stem and roots in the first and second seasons except for humic acid alone at $5 \mathrm{ml} / 1$ which resulted the highest significant value of stem dry weight in the first season only.

Improvement of vegetative and root growth due to treating with humic acid, it attributed to that improves nutrients relation in the media and increasing the water holding capacity (Dorer and Peacock, 1997) and also, BioHorm is a natural enzymatic activators supplying the plants with vitamins and amino acids which directly influence the physiological activities in plant growth and development (Datir et al., 2012). Also, ElSayed et al. (2015) showed that adding the 
Boshra A. El-Sayed et al.

Table 3. Effect of fertilization treatments on some vegetative and root growth of Cycas revoluta Thunb. plants during 2014 and 2015 seasons.

\begin{tabular}{|c|c|c|c|c|c|}
\hline Fertilization treatments & $\begin{array}{l}\text { Plant height } \\
\text { (cm) }\end{array}$ & $\begin{array}{c}\text { No. leaves/ } \\
\text { plant }\end{array}$ & $\begin{array}{c}\text { Stem diameter } \\
(\mathrm{cm})\end{array}$ & $\begin{array}{l}\text { No. roots/ } \\
\text { plant }\end{array}$ & $\begin{array}{l}\text { Root length } \\
\text { (cm) }\end{array}$ \\
\hline & \multicolumn{5}{|c|}{ First season: 2014} \\
\hline Control & $40.20 \mathrm{e}$ & $2.33 \mathrm{c}$ & $4.50 \mathrm{c}$ & $3.67 \mathrm{c}$ & $19.67 \mathrm{c}$ \\
\hline Humic acid at $5 \mathrm{ml} / \mathrm{l}$ (A) & $55.00 \mathrm{bc}$ & $3.00 \mathrm{abc}$ & $5.50 \mathrm{~b}$ & $5.67 \mathrm{~b}$ & $24.00 \mathrm{c}$ \\
\hline BioHorm at 1 ml/l (B) & $42.67 \mathrm{de}$ & $2.67 \mathrm{bc}$ & $5.00 \mathrm{bc}$ & $6.00 \mathrm{~b}$ & $22.33 \mathrm{c}$ \\
\hline BioHorm at $3 \mathrm{ml} / \mathrm{l}(\mathrm{C})$ & $50.00 \mathrm{~cd}$ & $3.00 \mathrm{abc}$ & $5.30 \mathrm{~b}$ & $7.00 \mathrm{ab}$ & $23.67 \mathrm{c}$ \\
\hline $\mathbf{A}+\mathbf{B}$ & $63.67 \mathrm{ab}$ & $3.33 \mathrm{ab}$ & $6.17 \mathrm{a}$ & $7.67 \mathrm{a}$ & $36.00 \mathrm{~b}$ \\
\hline \multirow[t]{2}{*}{$\mathbf{A}+\mathbf{C}$} & $67.00 \mathrm{a}$ & $3.67 \mathrm{a}$ & $6.47 \mathrm{a}$ & $8.33 \mathrm{a}$ & $47.00 \mathrm{a}$ \\
\hline & \multicolumn{5}{|c|}{ Second season: 2015} \\
\hline Control & $43.00 \mathrm{e}$ & $2.33 \mathrm{~b}$ & $4.85 \mathrm{~b}$ & $3.93 \mathrm{c}$ & $21.00 \mathrm{c}$ \\
\hline Humic acid at $5 \mathrm{ml} / \mathrm{l}$ (A) & $57.83 \mathrm{bc}$ & $3.33 \mathrm{ab}$ & $7.00 \mathrm{a}$ & $6.03 \mathrm{~b}$ & $25.60 \mathrm{c}$ \\
\hline BioHorm at $1 \mathrm{ml} / \mathrm{l}$ (B) & $46.17 \mathrm{de}$ & $3.33 \mathrm{ab}$ & $5.48 \mathrm{ab}$ & $6.52 \mathrm{~b}$ & $23.86 \mathrm{c}$ \\
\hline BioHorm at $3 \mathrm{ml} / \mathrm{l}(\mathrm{C})$ & $54.67 \mathrm{~cd}$ & $3.33 \mathrm{ab}$ & $5.88 \mathrm{ab}$ & $7.61 \mathrm{ab}$ & $25.78 \mathrm{c}$ \\
\hline $\mathbf{A}+\mathbf{B}$ & $67.00 \mathrm{ab}$ & $3.33 \mathrm{ab}$ & $6.56 \mathrm{a}$ & $8.42 \mathrm{a}$ & $39.09 \mathrm{~b}$ \\
\hline $\mathbf{A}+\mathbf{C}$ & $71.00 \mathrm{a}$ & $3.67 \mathrm{a}$ & $7.05 \mathrm{a}$ & $8.92 \mathrm{a}$ & $51.70 \mathrm{a}$ \\
\hline
\end{tabular}

* Means within a column having the same letters are not significantly different according to Duncan's Multiple Range Test at 5\% level.

Table 4. Effect of fertilization treatments on fresh and dry weights of Cycas revoluta Thunb. plants during 2014 and 2015 seasons.

\begin{tabular}{|c|c|c|c|c|c|c|}
\hline \multirow{2}{*}{ Fertilization treatments } & \multicolumn{3}{|c|}{ Fresh weight (g) } & \multicolumn{3}{|c|}{ Dry weight (g) } \\
\hline & Leaves & Stem & Roots & Leaves & Stem & Roots \\
\hline & \multicolumn{6}{|c|}{ First season: 2014} \\
\hline Control & $40.49 \mathrm{f}$ & $49.25 \mathrm{f}$ & $37.50 \mathrm{e}$ & $18.20 \mathrm{c}$ & $19.62 \mathrm{f}$ & $18.00 \mathrm{~d}$ \\
\hline Humic acid at $5 \mathrm{ml} / \mathrm{l}$ (A) & $53.01 \mathrm{c}$ & $60.00 \mathrm{c}$ & $39.60 \mathrm{c}$ & $19.20 \mathrm{~b}$ & $39.99 \mathrm{a}$ & $18.99 \mathrm{c}$ \\
\hline BioHorm at $1 \mathrm{ml} / \mathrm{l}$ (B) & $44.22 \mathrm{e}$ & $55.10 \mathrm{e}$ & $37.99 \mathrm{de}$ & $18.17 \mathrm{c}$ & $24.25 \mathrm{e}$ & $18.63 \mathrm{~cd}$ \\
\hline BioHorm at $3 \mathrm{ml} / \mathrm{l}(\mathrm{C})$ & $47.98 \mathrm{~d}$ & $58.34 \mathrm{~d}$ & $38.90 \mathrm{~cd}$ & $19.76 \mathrm{~b}$ & $26.34 \mathrm{~d}$ & $18.45 \mathrm{~cd}$ \\
\hline $\mathbf{A}+\mathbf{B}$ & $55.62 \mathrm{~b}$ & $63.42 \mathrm{~b}$ & $45.29 \mathrm{~b}$ & $23.99 \mathrm{a}$ & $31.22 \mathrm{c}$ & $24.23 \mathrm{~b}$ \\
\hline \multirow[t]{2}{*}{$\mathbf{A}+\mathbf{C}$} & $59.24 \mathrm{a}$ & $77.22 \mathrm{a}$ & $49.01 \mathrm{a}$ & $24.33 \mathrm{a}$ & $35.33 \mathrm{~b}$ & $25.99 \mathrm{a}$ \\
\hline & \multicolumn{6}{|c|}{ Second season: 2015} \\
\hline Control & $37.22 \mathrm{e}$ & $39.21 \mathrm{~d}$ & $30.20 \mathrm{~d}$ & $20.01 \mathrm{c}$ & $21.48 \mathrm{f}$ & $19.83 \mathrm{c}$ \\
\hline Humic acid at 5 ml/l (A) & $54.11 \mathrm{c}$ & $59.99 \mathrm{~b}$ & $51.22 \mathrm{bc}$ & $20.55 \mathrm{bc}$ & $39.13 \mathrm{~b}$ & $20.67 \mathrm{c}$ \\
\hline BioHorm at $1 \mathrm{ml} / \mathrm{l}$ (B) & $43.22 \mathrm{~d}$ & $53.11 \mathrm{c}$ & $49.21 \mathrm{c}$ & $19.69 \mathrm{c}$ & $26.40 \mathrm{e}$ & $20.04 \mathrm{c}$ \\
\hline BioHorm at $3 \mathrm{ml} / \mathrm{l}(\mathrm{C})$ & $45.35 \mathrm{~d}$ & $55.00 \mathrm{c}$ & $50.00 \mathrm{bc}$ & $21.54 \mathrm{~b}$ & $28.65 \mathrm{~d}$ & $20.00 \mathrm{c}$ \\
\hline $\mathbf{A}+\mathbf{B}$ & $57.27 \mathrm{~b}$ & $60.21 \mathrm{~b}$ & $53.00 \mathrm{ab}$ & $26.40 \mathrm{a}$ & $34.05 \mathrm{c}$ & $26.16 \mathrm{~b}$ \\
\hline $\mathbf{A}+\mathbf{C}$ & $60.72 \mathrm{a}$ & $73.50 \mathrm{a}$ & $55.02 \mathrm{a}$ & $26.76 \mathrm{a}$ & $43.23 \mathrm{a}$ & $27.98 \mathrm{a}$ \\
\hline
\end{tabular}

* Means within a column having the same letters are not significantly different according to Duncan's Multiple Range Test at 5\% level. 
natural activators during the growth stage gave the best performance and highest quality of seashore paspalum turf.

\section{Chemical composition:}

Data averaged in Table (5) indicated that there was a significant effect of different treatments on pigments content (chlorophyll $\mathrm{a}, \mathrm{b}$ and carotenoids) in the leaves ( $\mathrm{mg} / \mathrm{g}$ f.w.) as treated plants with humic acid at 5 $\mathrm{ml} / \mathrm{l}$ individualy or in combination with BioHorm at 1 and $3 \mathrm{ml} / 1$ increased the leaf content of chlorophyll $\mathrm{a}, \mathrm{b}$ and carotenoids (mg/g f.w.) over control means in the two seasons, with the dominance of humic acid at $5 \mathrm{ml} / \mathrm{l}+$ BioHorm at $3 \mathrm{ml} / \mathrm{l}$.

With regard to total indoles content (mg/100 g f.w.), as it was significantly increased in response to the different treatments employed in this work with the humic acid alone at $5 \mathrm{ml} / 1$ individually or added to BioHorm at $3 \mathrm{ml} / 1$ in the two seasons. The opposite was the right concerning the content of total phenols which was slightly decreased in the two seasons by the individual and combination between humic acid at $5 \mathrm{ml} / 1+3 \mathrm{ml} / 1$ BioHorm.

As shown in Table (6) it is clear that the percentages of $\mathrm{N}, \mathrm{P}$ and $\mathrm{K}$ and total carbohydrates in the leaves were markedly increased as a result to spraying with humic acid at $5 \mathrm{ml} / 1+$ BioHorm at $3 \mathrm{ml} / 1$ which registered the highest values at all. This may indicate the effect of both humic acid and the natural activator "BioHorm".

These results are supported by El-Sayed et al. (2015) on paspalum turf. Kenneth (1979) reported that the total of plant growth is used not a single hormonal type that of auxin, cytokinins, gibberllins and ethylene, and this further is subjected to modification by certain naturally occurring inhibitors namely phenols, flavonols and absicsic acid, which have been known to modify the activity of IAA-oxidase and might therefore be acting on growth and production by way of changes in endogenous auxin level. In addition, cytokinin has the ability to prevent the emanation of some positive inhibitory influences from the leaves under noninductive conditions (Audus, 1972).

From the aforementioned results, it could be recommended to spray the 2 yearsold plants of Cycas revoluta, Thunb. cultivated in $20-\mathrm{cm}$-diameter plastic pots filled with about $2.5 \mathrm{~kg}$ of sand:clay:peatmoss mixture $(1: 1: 1, \mathrm{v}: \mathrm{v}: \mathrm{v})$ with humic acid at $5 \mathrm{ml} / \mathrm{l}+3 \mathrm{ml} / 1$ BioHorm for obtaining healthy growth and high quality plants.

\section{REFERENCES}

A.O.A.C. (1990). Association of Official Agricultural Chemists "Official Methods of Analysis of the Association of Official Agricultural Chemists". $15^{\text {th }}$ Ed., Arlington, Virginia 22201:877-878.

Audus, L.J. (1972). Plant Growth Substances. Vol.1: Chemistry and Physiology. Leonard Hill Books, 158 Buckingham Palace Road, London, $3^{\text {rd }}$ Ed., 533 pp.

Bailey, L.H. (1950). The Standard Cyclopedia of Horticulture, Vol. I (A-E). The Macmillan Company, New York, U.S.A., 1200 pp.

Cottenie, A.; Verloo, M.; Kiekan, L.; Velghe, G. and Comerlynck, R. (1982). Chemical Analysis of Plants and Soils. Laboratory of Analytical and Agrochemistry. State Univ., GhentBelgium, p:44-45.

Datir, R.B.; Apparao, B.J. and Laware, S.L. (2012). Application of amino acid chelated micronutrients for enhancing growth and productivity in Chili (Capsicum annum L.). Plant Sciences Feed, 2(7):100-105.

Dorer, S.P. and Peacock, C.H. (1997). The effect of humate and organic fertilizer on establishment and nutrition of creeping bentgrass putting greens. Inter. Turfgrass Soc. Res. J., 8:437-443.

Duncan, D.B. (1955). Multiple range and multiple F. tests, Biometrics, 11:1- 24. 
Boshra A. El-Sayed et al.

Table 5. Effect of fertilization treatments on some chemical constituents of Cycas revoluta Thunb. leaves during 2014 and 2015 seasons.

\begin{tabular}{|c|c|c|c|c|c|}
\hline \multirow{2}{*}{ Fertilization treatments } & \multicolumn{3}{|c|}{ Photosynthetic pigments (mg/g f.w.) } & \multirow{2}{*}{$\begin{array}{l}\text { Total indoles } \\
\text { (mg/100 g f.w.) }\end{array}$} & \multirow{2}{*}{$\begin{array}{l}\text { Total phenols } \\
\text { (mg/100 g f.w.) }\end{array}$} \\
\hline & Chl. a & Chl. b & Carotenoids & & \\
\hline & \multicolumn{5}{|c|}{ First season: 2014} \\
\hline Control & $0.401 \mathrm{e}$ & $0.136 \mathrm{f}$ & $0.210 \mathrm{e}$ & $0.431 \mathrm{e}$ & $0.051 \mathrm{a}$ \\
\hline Humic acid at $5 \mathrm{ml} / \mathrm{l}$ (A) & $0.901 \mathrm{c}$ & $0.331 \mathrm{c}$ & $0.494 \mathrm{c}$ & $0.514 \mathrm{c}$ & $0.021 \mathrm{c}$ \\
\hline BioHorm at 1 ml/l (B) & $0.634 \mathrm{~d}$ & $0.159 \mathrm{e}$ & $0.332 \mathrm{~d}$ & $0.483 \mathrm{~d}$ & $0.042 \mathrm{~b}$ \\
\hline BioHorm at 3 ml/l (C) & $0.898 \mathrm{c}$ & $0.172 \mathrm{~d}$ & $0.339 \mathrm{~d}$ & $0.499 \mathrm{~cd}$ & $0.023 \mathrm{c}$ \\
\hline $\mathbf{A}+\mathbf{B}$ & $1.439 \mathrm{~b}$ & $0.371 \mathrm{~b}$ & $0.541 \mathrm{~b}$ & $0.675 \mathrm{~b}$ & $0.012 \mathrm{~d}$ \\
\hline \multirow[t]{2}{*}{$\mathbf{A}+\mathbf{C}$} & $1.601 \mathrm{a}$ & $0.542 \mathrm{a}$ & $0.579 \mathrm{a}$ & $0.794 \mathrm{a}$ & $0.010 \mathrm{~d}$ \\
\hline & \multicolumn{5}{|c|}{ Second season: 2015} \\
\hline Control & $0.420 \mathrm{~d}$ & $0.139 \mathrm{f}$ & $0.209 \mathrm{f}$ & $0.498 \mathrm{c}$ & $0.051 \mathrm{a}$ \\
\hline Humic acid at 5 ml/l (A) & $0.901 \mathrm{~b}$ & $0.345 \mathrm{c}$ & $0.432 \mathrm{c}$ & $0.547 \mathrm{~b}$ & $0.036 \mathrm{c}$ \\
\hline BioHorm at 1 ml/l (B) & $0.633 \mathrm{c}$ & $0.162 \mathrm{e}$ & $0.330 \mathrm{e}$ & $0.490 \mathrm{c}$ & $0.045 \mathrm{~b}$ \\
\hline BioHorm at $3 \mathrm{ml} / \mathrm{l}$ (C) & $0.897 \mathrm{~b}$ & $0.183 \mathrm{~d}$ & $0.339 \mathrm{~d}$ & $0.499 \mathrm{c}$ & $0.031 \mathrm{~d}$ \\
\hline $\mathbf{A}+\mathbf{B}$ & $1.581 \mathrm{a}$ & $0.362 \mathrm{~b}$ & $0.499 \mathrm{~b}$ & $0.549 \mathrm{~b}$ & $0.030 \mathrm{~d}$ \\
\hline $\mathbf{A}+\mathbf{C}$ & $1.603 \mathrm{a}$ & $0.548 \mathrm{a}$ & $0.521 \mathrm{a}$ & $0.699 \mathrm{a}$ & $0.011 \mathrm{e}$ \\
\hline
\end{tabular}

* Means within a column having the same letters are not significantly different according to Duncan's Multiple Range Test at 5\% level.

Table 6. Effect of fertilization treatments on N, P, K and total carbohydrates of Cycas revoluta Thunb. leaves during 2014 and 2015 seasons.

\begin{tabular}{|c|c|c|c|c|}
\hline $\begin{array}{l}\text { Fertilization } \\
\text { treatments }\end{array}$ & N (\%) & $P(\%)$ & K $(\%)$ & $\begin{array}{c}\text { Total carbohydrates } \\
\text { (\%) }\end{array}$ \\
\hline
\end{tabular}

\begin{tabular}{|c|c|c|c|c|}
\hline Control & $1.990 \mathrm{~d}$ & $0.113 \mathrm{f}$ & $0.806 \mathrm{e}$ & $16.38 \mathrm{e}$ \\
\hline Humic acid at $5 \mathrm{ml} / \mathrm{l}$ & $2.212 \mathrm{~b}$ & $0.126 \mathrm{e}$ & $0.921 \mathrm{~d}$ & $17.11 \mathrm{~d}$ \\
\hline BioHorm at $1 \mathrm{ml} / \mathrm{l}$ & $2.000 \mathrm{~d}$ & $0.154 \mathrm{~d}$ & $1.111 \mathrm{bc}$ & $17.99 \mathrm{c}$ \\
\hline BioHorm at $3 \mathrm{ml} / \mathrm{l}$ & $2.120 \mathrm{c}$ & $0.201 \mathrm{c}$ & $1.109 \mathrm{c}$ & $18.00 \mathrm{c}$ \\
\hline $\mathbf{A}+\mathbf{B}$ & $2.300 \mathrm{a}$ & $0.215 \mathrm{~b}$ & $1.129 \mathrm{~b}$ & $18.99 \mathrm{~b}$ \\
\hline \multirow[t]{2}{*}{$\mathbf{A}+\mathbf{C}$} & $2.310 \mathrm{a}$ & $0.321 \mathrm{a}$ & $1.530 \mathrm{a}$ & $20.00 \mathrm{a}$ \\
\hline & \multicolumn{4}{|c|}{ Second season: 2015} \\
\hline Control & $1.480 \mathrm{~d}$ & $0.102 \mathrm{e}$ & $0.702 \mathrm{f}$ & $15.99 \mathrm{e}$ \\
\hline Humic acid at $5 \mathrm{ml} / \mathrm{l}$ & $2.200 \mathrm{~b}$ & $0.109 \mathrm{e}$ & $0.821 \mathrm{e}$ & $16.32 \mathrm{~d}$ \\
\hline BioHorm at $1 \mathrm{ml} / \mathbf{l}$ & $1.950 \mathrm{c}$ & $0.140 \mathrm{~d}$ & $0.999 \mathrm{~d}$ & $17.21 \mathrm{c}$ \\
\hline BioHorm at $3 \mathrm{ml} / \mathrm{l}$ & $1.970 \mathrm{c}$ & $0.190 \mathrm{c}$ & $1.101 \mathrm{c}$ & $17.99 \mathrm{~b}$ \\
\hline $\mathbf{A}+\mathbf{B}$ & $2.160 \mathrm{~b}$ & $0.199 \mathrm{~b}$ & $1.132 \mathrm{~b}$ & $18.22 \mathrm{~b}$ \\
\hline $\mathbf{A}+\mathbf{C}$ & $2.390 \mathrm{a}$ & $0.219 \mathrm{a}$ & $1.321 \mathrm{a}$ & $19.99 \mathrm{a}$ \\
\hline
\end{tabular}


El-Fouly, Amal S.; El-Sayed, Boshra A. and S.M. Shahin (2014). Effect of foliar spraying with humic acid and chelated microelements on growth and quality of goodluck (Cordyline terminalis (L.) Kunth.) plant. Minufiya J. Agric. Res., 39(1):205-213.

El-Sayed, Boshra A.; Noor El-Deen, T.M.; Ahmed, Magda A. and Shahin, S.M. (2015). Effect of some natural activators on growth and quality of seashore paspalum turf. Proc. The $1^{\text {st }}$ Conf. SSFOP "Future of Ornamental Plants in Egypt", Cairo, Egypt. 22/2/2015. Scientific J. Flowers and Ornamental Plants, 2(1):149-156.

El-Sayed, Boshra A. (2012). Improving growth and quality of seashore paspalum turf by actosol and Oligo-X. J. Biol. Chem. \& Environ. Sci., 7(2):77-87.

El-Sherbeny, Soheir E., Hendawy, S.F.; Youssef, A.A.; Naguib, N.Y. and Hussein, M.S. (2012). Response of turnip (Brassica rapa) plants to minerals or organic fertilizers treatments. Journal of Applied Sciences Research, 8(2):628634.

Evans, M. and Li, G. (2003). Effect of humic acids on growth of annual ornamental seeding plugs. HortTechnology, 13(4):661-665.

Herbert, D.; Philips, P.J. and Strange, R.E. (1971) Determination of total carbohydrates. Methods in Microbiology, 5(8):290-344.

Jackson, M.L. (1973). Soil Chemical Analysis. Prentice-Hall of India Private Limited M-97, New Delhi, India, 498 pp.

Kenneth, V.T. (1979). Physiology of Plant Growth and Development. B. Willkins TaTa, McGraw-Hill Publishing Co. Ltd., New Delhi.

Mead, R.; Curnow, R.N. and Harted, A.M. (1993). Statistical Methods in Agriculture and Experimental Biology, $2^{\text {nd }}$ Ed., Chapman \& Hall Ltd., London, 335 pp.

Moran, R. (1982). Formula for determination of pigments extracted with $\mathrm{N}, \mathrm{N}$ dimethyl formamide. Plant Physiol., 69:1376-1381.

Saric, M.; Kastrori, R.; Curic, R.; Cupina T. and Geric, I. (1967). Chlorophyll Determination. Univ U Noven Sadu Praktikum is Fiziologize Biljaka, Beogard, Haucna, Anjiga, 215 pp.

SAS Institute Program (1994). SAS/STAT User's Guide, Statistics. Vers. 6.04, $4^{\text {th }}$ Ed., SAS Institute Inc. Cary, N.C., USA.

William, M.; Chichlilo, P.; Clifford, P.A. and Reynolds, M. (1965). Official Methods of Analysis of the Association of Official Agriculture Chemists, $10^{\text {th }}$ Ed., Washington D.C. 20044:52-55.

\footnotetext{
تأثير المنشط الطبيعي (بيوهورم) وحمض الهيوميك على نمو وجودة نباتات السيكاس

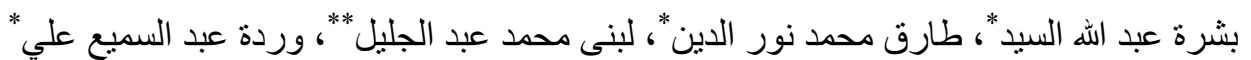

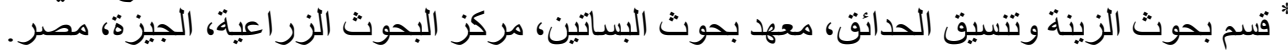
** المعمل المركزي لأبحاث وتطوير نخيل البلح، معهد بحوث البساتين، مركز البحوث البحث الزبن الزراعية، الجيزة، مصر.

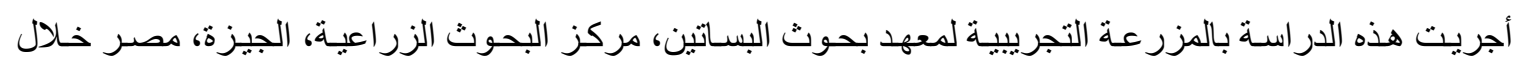

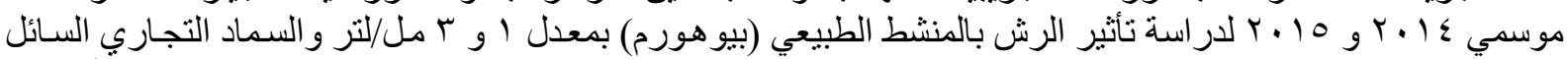



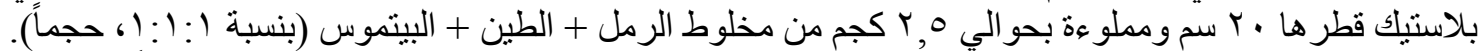

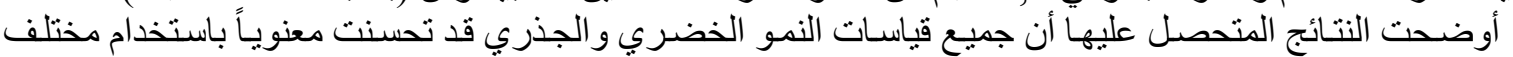

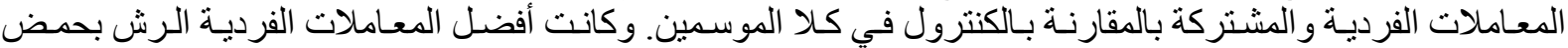

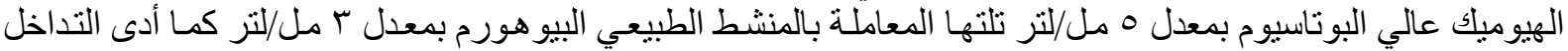

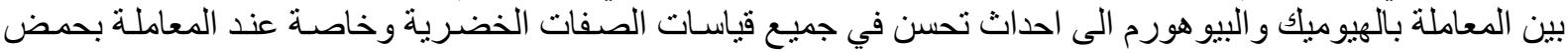




\section{Boshra A. El-Sayed et al.}

الهيوميك عالي البوتاسيوم بمعدل ه مل/لتر + المنشط الطبيعي بيو هورم بمعدل ب مل/لتر التي التي أعطت أعلى متوسطات



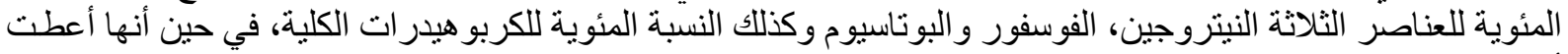

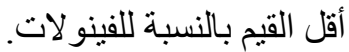

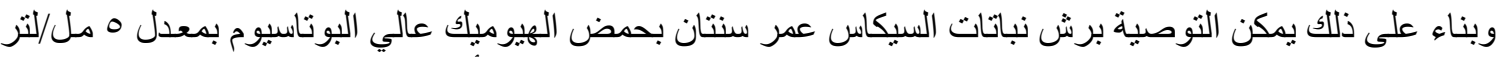

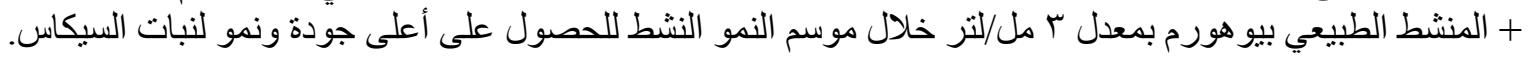

